\title{
Factors Affecting the Intention to Establish Innovative Business Based on Local Resources in Young Generation on North Sulawesi
}

\author{
Christoffel Kojo*, Christoffel M. O. Mintardjo, Djeini Maradesa, Wensy F. I. Rompas \\ Faculty of Economy and Business \\ Universitas Sam Ratulangi \\ Manado, Indonesia \\ *christoffelkojo@gmail.com, christoffelmintardjo@unsrat.ac.id
}

\begin{abstract}
The problem in North Sulawesi is the lack of innovation and creativity of the younger generation, especially in establishing business and creating innovative and creative products and services. The importance of this problem is because young people who can set up a business and create innovative products and services will drive the innovation economy in North Sulawesi. To be able to drive the innovation-based economy it is necessary to create many innovative entrepreneurs, especially those based on local resources such as the marine industry, fisheries, and tourism. This study aims to investigate the factors that influence the intentions of young people to pursue innovative and creative entrepreneurs based on local resources. The model analyzed includes internal factors, attitude factors towards entrepreneurship and contextual factors. This study involved a sample of 200 young generation respondents in North Sulawesi obtained using a purposive sampling technique. The research method is quantitative with the regression analysis and hypothesis testing t-test and F-test. The results of the study that several factors influence the intention of innovative entrepreneurs in the younger generation.
\end{abstract}

Keywords: intention, innovative business, local resources, young generation, North Sulawesi

\section{INTRODUCTION}

Indonesia is now faced with the problem of increasing economic growth to face globalization, rapid change in technology, also climate change [1], therefore the government has begun to intensify entrepreneurial intentions by inserting entrepreneurial material in lectures to equip entrepreneurship students who will arouse entrepreneurial intensity in themselves. Increased economic growth is felt to have not been able to overcome the problem of poverty `and the provision of jobs, therefore the government increased entrepreneurial intentions for students who will face the globalization, technological change and climate change. The problem of unemployment is a problem faced by every country [2]. For decades unemployment has risen. In Indonesia, the highest unemployment rate is created by educated groups [3].

The phenomenon of unemployment rates in Indonesia and North Sulawesi is quite high, the intention of entrepreneurship must be set in the community to reduce the number of unemployed which is a problem in facing the globalization of the state of Indonesia and the province of North Sulawesi. The intention is related to an indication of how difficult a person is trying to understand, how much effort someone has in planning something, to do a certain behavior [4]

Factors that influence entrepreneurial intentions, which are: personality factors, which affect entrepreneurial intentions include, the need for achievement, self-efficacy, locus of control, and risk-taking [5]. Environmental factors include access to capital, information from social networks, in addition to physical and institutional infrastructure factors, and cultural factors also influence entrepreneurial intentions. Demographic factors include gender, age, educational background, parents' occupation, and work experience affecting entrepreneurial intentions.

Based on a brief presentation in the previous introduction, the objectives of this study are: (1) to examine the effect of entrepreneurial motivation on student entrepreneurship intentions; (2) examine the effect of the need for achievement on student entrepreneurship intentions; (3) examines the effect of entrepreneurship education on the contribution of ideas and input for prospective entrepreneurs, students and the society related to entrepreneurship, especially regarding the influence of entrepreneurship motivation, freedom of achievement, and entrepreneurship education on entrepreneurial intentions as well as consideration in applying variables this research variable in an effort to develop entrepreneurial intentions.

\section{THEORETICAL FRAMEWORK}

\section{A. Entrepreneurship}

Entrepreneurs are known in various terms and names including: entrepreneurs, business persons, traders, technopreneur, marketer, even salesperson, and so on. However, all the terms and concepts are similar which refers to an understanding, that is someone who is doing or setting up his/her own business with the aim of gaining profit [2].

The term entrepreneur is taken from the root of the French word meaning between taker or go-between [6]. Entrepreneurs 
consist of three words, which are: entre, pre, and neur. According to its Latin roots, entre (English: enter) which means entry, pre (English: pre) means before, and neur (English: nerve) means nerve/central nerve. Thus, an entrepreneur is defined as someone who enters the business world (any business or business) in time to form or change the nerve center of the business substantially [7]. Some literature, scientists, researchers have tried to define this entrepreneur.

Entrepreneurs play an important role in the economic development of a region, nation, and state. Entrepreneur figures emphasize that they play an important role in higher economies and exceed the roles played by managers and capital owners. The economic function of entrepreneurs gives us a sign of how important their role is as a development agent. Based on this, the entrepreneur is responsible for the progress of the business and business; they provide dynamism with economic activity in their area; manage organizational and technical changes; and also fostering a culture of innovation and learning in that environment [8].

Entrepreneurs from the perspective of economic theory and management, are people who specialize in the application of valuations in economic decision making, where good judgment leads to innovation in the utilization of time and the creation of profit opportunities [9]. Talented entrepreneurs will build their business in areas they understand and feel capable based on sophisticated assessments and calculations, even those entrepreneurs have to take control of existing companies. The demand and supply of entrepreneurship in the economy occur where entrepreneurial demand is driven by volatility, or changes in the economic environment, while entrepreneurial supply is determined by the number of people with appropriate personality characteristics (entrepreneurial personality). The interaction between entrepreneurial demand and supply is determined by the income of entrepreneurs, and a large amount of availability of entrepreneurs who are active in the economic field [9].

\section{B. Entrepreneur Motivation}

Motivation is an impetus that has been bound to a goal, many theories to understand the motivation. One theory is the process, which seeks to explain the process of arising from one's desire to display certain behaviors. This theory tries to describe the process that occurs in the mind of someone who finally someone is displaying certain behaviors [10]. This theory is as follows: Equity Theory (Vroom) This theory, indicates that basically humans like fair treatment. Humans will be motivated to work well when treated fairly. The Vroom Expectancy Theory, the size of the work effort that will be shown by someone, depends on how this person views the possibility of success from his behavior in achieving or avoiding it. Other theories about motives must be studied and understood, to direct this motivation toward expected behavior.

According to Alma [6], in carrying out entrepreneurship must have a strong motivation, motivation in question is a process in which a person behaves to achieve the goal to satisfy his needs. This is because an entrepreneur automatically wants the success of his business, therefore there needs to be a strong push to achieve business success. One of the main characteristics of entrepreneurial behavior is the need for achievement which is the need to excel and to achieve certain goals in objective personal achievement [11]. According to McClelland's theory [12], the need for achievement is a person who carries out entrepreneurial activities driven by the desire to get achievements and recognition from family and society. The need for achievement indicates a person's desire to make something or work better, or faster than other people's achievements or past achievements [13].

\section{Entrepreneur Intention}

Entrepreneurial intention can be interpreted as the initial step of a process of establishing a business that is generally long-term in nature [14]. Entrepreneurial intention can be defined as a state of mind that directs and guides every individual towards the development, and implementation of new business concepts [2].

Intention is an awareness of future-oriented thinking that includes both an outcome (or an objective) and an action plan to achieve that outcome [15], which can be considered as key constructs in the behavior of entrepreneurship and determinants of entrepreneurial action. Intention can be a determinant of entrepreneurial action, although the correlation between intention and action in many empirical studies is still weak [16]. Entrepreneurial intentions primarily aim to create a new business and create new values or innovate in an existing company [17]. Intention includes location dimensions, namely entrepreneurial intentions (internal locus), as well as the intentions of stakeholders, markets, and others (external loci). In addition, there are other dimensions of entrepreneurial intentions, namely rational and intuitive. The rationale in entrepreneurial intentions includes the processes that underlie formal business planning, opportunity analysis, resource takeover, goal setting, and observable goal-oriented behavior. While intuitive in entrepreneurial intentions in the form of structure and frame of mind of the intentions, and actions of entrepreneurs. This intusion is based on a vision, hunch, and an expanded view of untapped resources, and a sense of the potential of effort and resilience of the entrepreneur [17].

A narrow relationship will exist between the intention to become an entrepreneur, and on its effective performance [18]. The intention is a fundamental element towards explaining behavior. This indicates that the effort that someone will make to bring about entrepreneurial behavior [18]. Based on the research, there are three main predictors of entrepreneurial intentions, which are [19]: (a) Attitudes toward behavior (Personal Attraction / PA) refer to the degree to which individuals hold positive or negative personal values about being an entrepreneur. (b) Perceived Social Norms (SN) will measure the perception of social pressures that carry or do not carry entrepreneurial behavior. In particular, it refers to the perception that "people who refer (reference people)" will approve the decision to become an entrepreneur, or not. (c) Perceived Behavioral Control (PBC) will be defined as the perception of ease or difficulty in achieving behavioral interests (being an entrepreneur/entrepreneur). 
TABLE I. VALIDITY TEST

\begin{tabular}{|l|c|c|c|c|}
\hline \multirow{2}{*}{ Var. } & \multirow{2}{*}{ Indic. } & \multicolumn{3}{|c|}{ Correlation (r) } \\
\cline { 2 - 5 } & $\mathrm{X} 1.1$ & 0.809 & 0.000 & Valid \\
\hline \multirow{4}{*}{ Attitude $\left(\mathrm{X}_{1}\right)$} & $\mathrm{X} 1.2$ & 0.944 & 0.000 & Valid \\
\cline { 2 - 5 } & $\mathrm{X} 1.3$ & 0.943 & 0.000 & Valid \\
\cline { 2 - 5 } & $\mathrm{X} 1.4$ & 0.868 & 0.000 & Valid \\
\cline { 2 - 5 } & $\mathrm{X} 1.5$ & 0.872 & 0.000 & Valid \\
\hline \multirow{4}{*}{$\begin{array}{l}\text { Social Norm } \\
\left(\mathrm{X}_{2}\right)\end{array}$} & $\mathrm{X} 2.1$ & 0.810 & 0.000 & Valid \\
\cline { 2 - 5 } & $\mathrm{X} 2.2$ & 0.925 & 0.000 & Valid \\
\cline { 2 - 5 } & $\mathrm{X} 2.3$ & 0.881 & 0.000 & Valid \\
\cline { 2 - 5 } & $\mathrm{X} 2.4$ & 0.767 & 0.000 & Valid \\
\cline { 2 - 5 } & $\mathrm{X} 2.5$ & 0.647 & 0.000 & Valid \\
\hline \multirow{4}{*}{$\begin{array}{l}\text { Perceived } \\
\text { Behavioral } \\
\text { Control (X) }\end{array}$} & $\mathrm{X} 3.1$ & 0.776 & 0.000 & Valid \\
\cline { 2 - 5 } & $\mathrm{X} 3.2$ & 0.871 & 0.000 & Valid \\
\cline { 2 - 5 } & $\mathrm{X} 3.3$ & 0.876 & 0.000 & Valid \\
\cline { 2 - 5 } & $\mathrm{X} 3.4$ & 0.731 & 0.000 & Valid \\
\cline { 2 - 5 } & $\mathrm{X} 3.5$ & 0.708 & 0.000 & Valid \\
\hline Entrepreneurial & $\mathrm{Y} 1.1$ & 0.925 & 0.000 & Valid \\
\cline { 2 - 5 } Intention & $\mathrm{Y} 1.2$ & 0.947 & 0.000 & Valid \\
\cline { 2 - 5 } $\begin{array}{l}\text { Establish } \\
\text { Inovative } \\
\text { Enterprises } \\
\text { Based on Local } \\
\text { Resources (Y) }\end{array}$ & $\mathrm{Y} 1.3$ & 0.966 & 0.000 & Valid \\
\cline { 2 - 5 } & $\mathrm{Y} 1.4$ & 0.934 & 0.000 & Valid \\
\cline { 2 - 5 } & $\mathrm{Y} 1.5$ & 0.951 & 0.000 & Valid \\
\hline
\end{tabular}

Based on test shown that all of the variables are valid with a high significant level (at the 0.01 level). Reliability test has shown in the Table 2 below:

TABLE II. RELIABILITY TEST

Research respondents were 141 male respondents $(56.4 \%)$, 109 female respondents (43.6\%). Aged less than 18 years as many as 8 respondents (3.2\%), aged between $18-20$ years as many as 140 respondents $(56 \%)$, aged between $21-25$ years as many as 76 respondents $(30.4 \%)$ and aged over 25 years 26 respondents (10.4\%). Have contracted entrepreneurship courses or related to it as many as 206 respondents $(82.4 \%)$, and never contracted similar subjects as much as 44 respondents (17.6\%). Having had experience working independently or doing business with family as many as 102 respondents $(40.8 \%)$, and had never had the experience of working independently and/or doing business independently or with a family of 148 respondents $(59.2 \%)$.

\begin{tabular}{|l|c|c|}
\hline \multicolumn{1}{|c|}{ Variable } & \multicolumn{1}{|c|}{$\begin{array}{c}\text { Alpha } \\
\text { Cronbach }\end{array}$} & Explanation \\
\hline Attitude $\left(\mathrm{X}_{1}\right)$ & 0.932 & Very Reliable \\
\hline Social Norm $\left(\mathrm{X}_{2}\right)$ & 0.862 & Very Reliable \\
\hline $\begin{array}{l}\text { Perceived Behavioral Control } \\
\left(\mathrm{X}_{3}\right)\end{array}$ & 0.854 & Very Reliable \\
\hline $\begin{array}{l}\text { Entrepreneurial Intention to } \\
\begin{array}{l}\text { Establish Inovative Enterprises } \\
\text { Based on Local Resources (Y) }\end{array}\end{array}$ & 0.969 & Very Reliable \\
\hline
\end{tabular}

Linear regression test used IBMSPSS aplication below it is the result.

TABLE III. MULTIPLE LINEAR REGRESSION ANALYSIS

\begin{tabular}{|c|c|c|c|c|c|}
\hline & Regression Coeef. (b) & Std Er & $t$ (count) & Sig. & Desc \\
\hline Constanta & 10.097 & 2.155 & 4.685 & 0.000 & \\
\hline Attitude (X1) & 0.521 & 0.063 & 8.232 & 0.000 & Sig \\
\hline Social Norm (X2) & 0.199 & 0.157 & 2.726 & 0.006 & Sig \\
\hline Perceived Behavioral Control (X3) & 0.068 & 0.065 & 2.348 & 0.006 & Sig \\
\hline \multicolumn{6}{|c|}{$Y=10,097+0,521 X 1+0,199 X 2+0,068 X 3+e$} \\
\hline $\mathrm{R}$ & $=$ & \multicolumn{4}{|c|}{0.503} \\
\hline R Square & $=$ & \multicolumn{4}{|c|}{0,253} \\
\hline F count & $=$ & \multicolumn{4}{|c|}{27,782} \\
\hline $\mathrm{t}$ table & $=$ & \multicolumn{4}{|c|}{2,008} \\
\hline Sig. F & $=$ & \multicolumn{4}{|c|}{0.000} \\
\hline $\mathrm{n}$ & $=$ & \multicolumn{4}{|c|}{250} \\
\hline$\alpha$ & $=$ & \multicolumn{4}{|c|}{$0.05(5 \%)$} \\
\hline
\end{tabular}


- There is an influence of entrepreneurial attitudes on the intention to establish innovative businesses based on local resources.

be seen in Table 3. The Fcount results $=27.782$ and Ftable $=$ 2,400. So it was found that Fcount $>F$ table with a significance level of $\operatorname{sig} F=0.0000<0.05$, this shows that $\mathrm{H} 0 \neg$ was rejected and $\mathrm{Ha}$ was accepted. Thus the $\mathrm{F}$ test results state that $\mathrm{HO}$ is rejected and $\mathrm{Ha}$ is accepted, meaning Entrepreneurial Attitude (X1), Entrepreneurial Social Environment (X2), Entrepreneurial Skills (X3) simultaneously have a significant effect on the Intention to Establish Innovative Enterprises Based on Local Resources (Y).

From the t-test results in Table it can be seen that the variable Entrepreneurial Attitude $(\mathrm{X} 1)$ tcount $=8.232>$ ttable $=$ 2.008 and a significant level of $0.000<0.05$, it can be concluded that $\mathrm{Ha}$ is accepted and $\mathrm{H} 0$ is rejected or Entrepreneurial Attitude (X1) has a significant effect on Intention to Establish Innovative Enterprises based on Local Resources (Y).

From the t test results in Table 3 it can be seen that the entrepreneurial Social Environment variable (X2) tcount = $2.726>$ ttable $=2.008$ and a significant level of $0.006<0.05$, it can be concluded that $\mathrm{Ha}$ is accepted and $\mathrm{HO}$ is rejected or Entrepreneurial Social Environment (X2) influences significant intention to Establish Innovative Enterprises based on Local Resources (Y).

From the t test results in Table 3 it can be seen that the variable Entrepreneurial Skills $(\mathrm{X} 3)$ tcount $=2.334>$ ttable $=$ 2.008 and a significant level of $0.006<0.05$, it can be concluded that $\mathrm{Ha}$ is accepted and $\mathrm{H} 0$ is rejected or Entrepreneurial Skills (X3) has a significant effect on Intention to Establish Innovative Enterprises based on Local Resources (Y).

Based on the calculation using the SPSS program as shown in Table 3, it can be seen that the value (R) produced is 0.503 which means it has a strong relationship. The value of $\mathrm{R}$ square is 0.253 or $25.3 \%$. It means that the influence of all independent variables, namely: Entrepreneurial Attitude (X1), Entrepreneurial Social Environment (X2), Entrepreneurial Skills (X3) on the independent variable Intention to Establish Innovative Enterprises Based on Local Resources (Y) is of $25.3 \%$ and the remaining 0.747 or $74.7 \%$ influenced by other variables outside this study.

These results are in accordance with or similar to previous studies including research from Mintardjo, Trang, and Mintardjo, who found an association between independent variables such as attitude, social environment and entrepreneurial skills on business intentions [3,20]. The difference is that entrepreneurship intentions in this study are about establishing innovative local resource-based businesses.

\section{CONCLUSION}

The results of research and discussion show that:

- There is an influence of entrepreneurial attitudes, social environment of entrepreneurship and entrepreneurial skills on the intention to establish innovative businesses based on local resources.
- There is an influence of the social environment of entrepreneurship on the intention to establish innovative businesses based on local resources.

- There is an influence of entrepreneurial skills on the intention to establish innovative businesses based on local resources.

Suggestions from this research are as follows:

- For further researchers, it is recommended to use a larger sample so that the results further strengthen the findings of this study.

- For further researchers, it is recommended to carry out research into entrepreneurial intentions especially to establish innovative businesses based on local resources.

\section{ACKNOWLEDGMENT}

This research was financially supported by the author and the Faculty of Economics and Business, Sam Ratulangi University (UNSRAT) Manado, Indonesia.

\section{REFERENCES}

[1] T. Friedman, Thank You for Being Late: An Optimist's Guide to Thriving in the Age of Acceleration, New York: Farrar, Straus and Giroux, 2017.

[2] C. M. O. Mintardjo, Pengantar Ilmu Kewirausahaan dan Manajemen Usaha Kecil Pemula, Latar Belakang, Teori, Terapan dan Kasus, 1 ed., Manado: Unsrat Press, 2017.

[3] C. M. O. Mintardjo, Faktor-Faktor yang memengaruhi Intensi Berwirausaha Mahasiswa di Kawasan Timur Indonesia (Studi pada Mahasiswa Fakultas Ekonomi Universitas Sam Ratulangi Manado). Dalam Malang: Program Doktor Ilmu Manajemen FEB UB, 2010, unpublished.

[4] R. D. Hisrich, M. P. Peters, and D. A. Shepherd, Entrepreneurship. Eleventh, New York: McGraw Hill Education, 2019.

[5] N. Indarti, dan R. Rostiani, "Students Entrepreneurial Intention: Comparing Indonesian, Japanese and Norwegian. Intensi kewirausahaan mahasiswa: studi perbandingan antara Indonesia, Jepang dan Norwegia" Jurnal Ekonomi dan Bisnis Indonesia, vol. 23, no. (4), pp. 369-84, 2008.

[6] B. Alma, Entrepreneurship. Kewirausahaan, Bandung: Alfabeta, 2010.

[7] L. E. Shefsky, Entrepreneurs are Made Not Born, New York: McGraw Hill, 2000.

[8] F. Liñán, Jc. Rodríguez-Cohard, and Jm.Rueda-Cantuche, "Factors affecting entrepreneurial intention levels," Paper presented at the $45^{\text {th }}$ Congress of the European Regional Science Association Amsterdam, 2005.

[9] M. Casson, "Entrepreneurship: Theory, Institutions, and History," Scandinavian Economic History Review, vol. 58, 2010.

[10] R. Lupiyoadi, Y. Suryana, Y. Wirasasmita, dan A. Mulyana, Jakarta: Mitra Wacana Media, 2016. Culturepreneurship, Membangkitkan Budaya Kewirausahaan Bangsa, 
[17] B. Bird, "Implementing Entrepreneurial Ideas: The Case for Intention" The Academy of Management Review, vol. 13, no. (3), pp. 442, Juli 1988.

Entrepreneurial Success: A Study of Entrepreneurs in Two Rura Industries in West Bengal," The Journal of Entrepreneurship, vol. 3, no. (2), pp. 191-204, 1994.

[12] D. C. McClelland, The Achieving Society, New York: Free Press, 1961.

[13] D. C. McClelland, Human Motivation, Illinois: Foresman, 1985.

[14] P. K. Wong, "Entrepreneurship, Innovation and Economic Growth: Evidence from GEM data," Small Business Economics, vol. 24, pp. 335-50, 2005.

[15] M. E. Tubbs, and S. E. Ekeberg, "The Role of Intentions in Work Motivation: Implications for Goal-Setting Theory and Research," Academy of Management Review, vol. 16, no. (1), pp.180-99, 1991.

[16] S. C. Santos, A. Caetano, C. Mitchell, H. Landstrom, and A. FAyolle, The Emergence of Entrepreneurial Behaviour: Intention, Education and Orientation, United Kingdom: Edward Elgar Publishing Inc, 2017.

[18] F. Liñán, and Y-W. Chen, "Testing The Entrepreneurial Intention Model On a Two-Country Sample," Working Paper, 2006.

[19] I. Ajzen, "The theory of planned behavior," Organizational Behavior and Human Decision Processes, vol. 50, no. (2), pp. 179-211, December 1991.

[20] I. Trang, and C. M. O. Mintardjo, "Entrepreneurial attitude, entrepreneurial social environment, and the entrepreneurial ability to entrepreneurial intensity to be young entrepreneur on Kabupaten Minahasa Induk," Journal of Awareness, vol. 3, no. (1), pp. 39-50, 2018. 